\title{
No-Mow Fineleaf Fescue Grasses for California
} Urban Landscapes

ALI HARIVANDI, University of California Environmental Horticulture Advisor, San Francisco Bay Area

The recent increase in demand for low-maintenance, low-input, environmentally friendly turf and landscape plants makes fineleaf fescue species prime candidates among "grassy" ground covers. Slopes, median strips, golf course roughs, cemeteries, untrafficked areas of parks, and industrial, commercial, and home landscapes are among the many potential sites for these grasses (fig. 1).

\section{What Is Fineleaf Fescue?}

Fineleaf fescue species have been available for use in mowed turf since the 1930s, but most did not come to market in large volume until the 1960s. Several improved cultivars were introduced after 1970. Recently, due to the low-input, low-maintenance nature of these versatile species, many new cultivars of fineleaf fescue have found their way to market and are becoming popular low-maintenance choices for a variety of uses.

The most common botanical categorization of fineleaf fescues, all of which are perennial, cool-season grasses, includes four distinct species: creeping red fescue (Festuca

Figure 1. Among the uses for no-mow fineleaf fescues are slopes, median strips, hard to mow sites, and anywhere in the landscape with minimal human traffic.
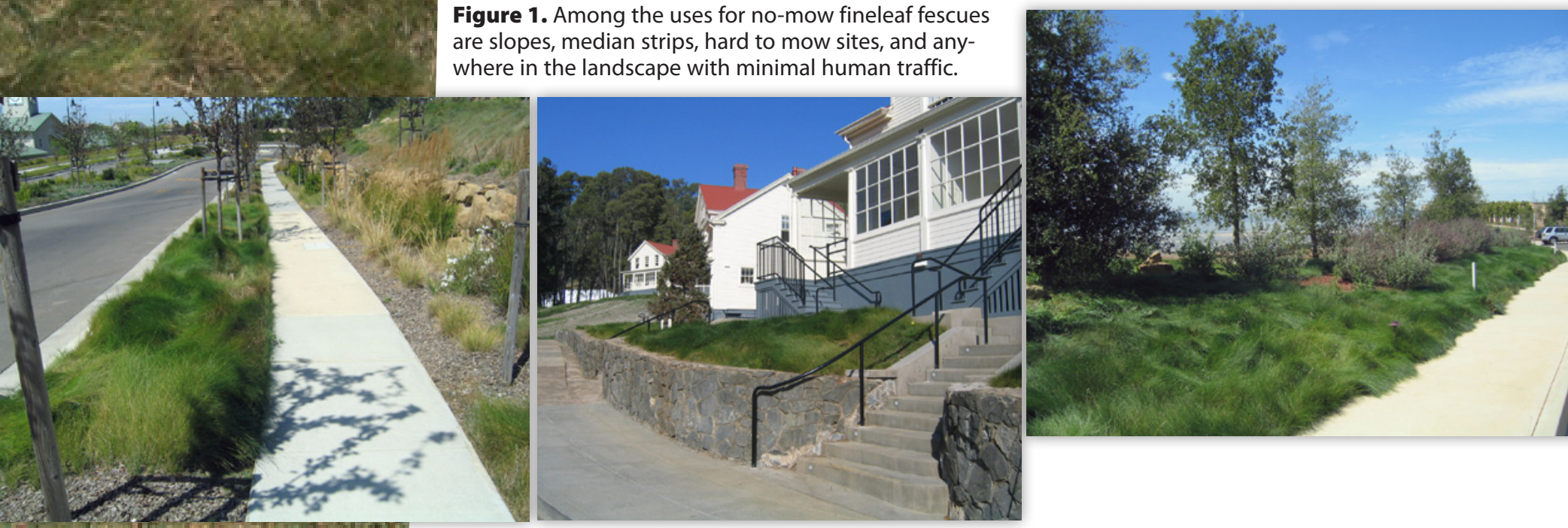
rubra); Chewings fescue (F. rubra ssp. fallax (comutata)); sheep fescue (F. ovina ssp. hirtula); and hard fescue (F. longifolia (brevipila)). Of these four, creeping red fescue, a native of Europe, is the most widely used for mowed turf purposes. It encompasses two distinct types: the first includes fine-leaved, low-growing grasses with short, thin rhizomes. Grasses of this type are weak creepers and therefore slow to fill bare areas. They are commonly known as slender creeping red fescue (Festuca rubra var. littoralis).

The second type of creeping red fescue (Festuca rubra ssp. rubra) is a strong creeper with long, spreading rhizomes and wider leaves. This type is not as tolerant of close mowing and grows less densely than the slender type; however, excellent seedling vigor accelerates its early establishment.

Both types of creeping red fescue are adapted to well-drained, dry, moderately shaded sites; they are especially intolerant of wet conditions. They require minimal levels of nitrogen and a $\mathrm{pH}$ of 5.5 to 6.5. Cutting heights of 1 to $2 \frac{1}{2}$ inches are common, with the higher heights preferred under shady conditions.

Chewings fescue, native to Europe, is lowgrowing and without rhizomes. It is a bunch-type grass that spreads very slowly, even under mowing, by basal tillering. It tolerates mowing as close as 1 to 1.5 inches where summers are cool; in warmer areas, mowing heights of 2 to 3 inches are best. Chewings fescue forms a denser turf than does creeping red fescue, especially under close mowing. It does not tolerate extremes in temperature but tolerates shade and drought well. It is adapted to well-drained, coarse-textured, acidic, infertile soils.

Sheep fescue, a noncreeping bunch-type grass with tufted, stiff, bluish-green leaves, is native to North America and Eurasia. It forms a relatively low-quality turf and has not been widely used for turfgrass purposes. Its main use is stabilization of well-drained, droughty, coarse-textured soils of low fertility. It is not adapted to close mowing or intensive culture.

Hard fescue, native to Europe, is a noncreeping bunch-type grass similar to sheep fescue but with tougher, wider, greener leaves. Its drought tolerance is less than that of sheep fescue but greater than that of creeping red fescue. It is quite deep-rooted and has a high root-to-shoot ratio, a major factor in its drought tolerance. Hard fescue is shade tolerant but does not adapt to close mowing. No-mow hard fescues are attractive ground covers and are often used for soil stabilization on roadsides and ditch banks, and for minimummaintenance and nonuse areas.

Fineleaf fescues are used as monostands (i.e., not in a mixture with other turf species) in several regions of the northern United States, but they are often unsuccessful as monostand mowed turf in California, especially in regions with hot summers. Shade tolerant, they are often used in seed mixtures with bluegrass and ryegrass in shady or semishady sites. As mowed monostands of turf, with the exception of the mountainous and the cool North Coastal regions, they do not produce a quality stand year-round in most parts of California, especially in full sun.

\section{Fineleaf Fescue Performance EVALUATION}

During the 1980s, the results of a trial at the UC Bay Area Research and Extension Center in Santa Clara revealed acceptable performance by several cultivars of fineleaf fescue when not mowed. In particular, hard fescue performed very well, and it was introduced to the landscape market as a no-mow, low-maintenance turfgrass ground cover. Since then, hard and other fineleaf fescues have been planted throughout California, particularly in the central coast and northern regions, as no-mow turf.

Further field observations of hard fescue performance in California have revealed its truly low-maintenance requirements when grown as a no-mow ground cover. In a multiyear, nonreplicated trial in Santa Clara, California, a plot of the hard fescue cultivar Scaldis, one-half mowed to 1.5 inches and the other half no-mow, received less than 2 pounds of nitrogen per 1,000 square feet per year and was irrigated with approximately 70 percent of the water received by other adjacent mowed coolseason turfgrasses. The mowed section of Scaldis thinned out considerably and was infested with weeds. The no-mow half, however, was consistently rated as acceptable for color and quality. With drooping leaves attaining not more than 12 inches in length and thinned seed heads, the stand appeared 

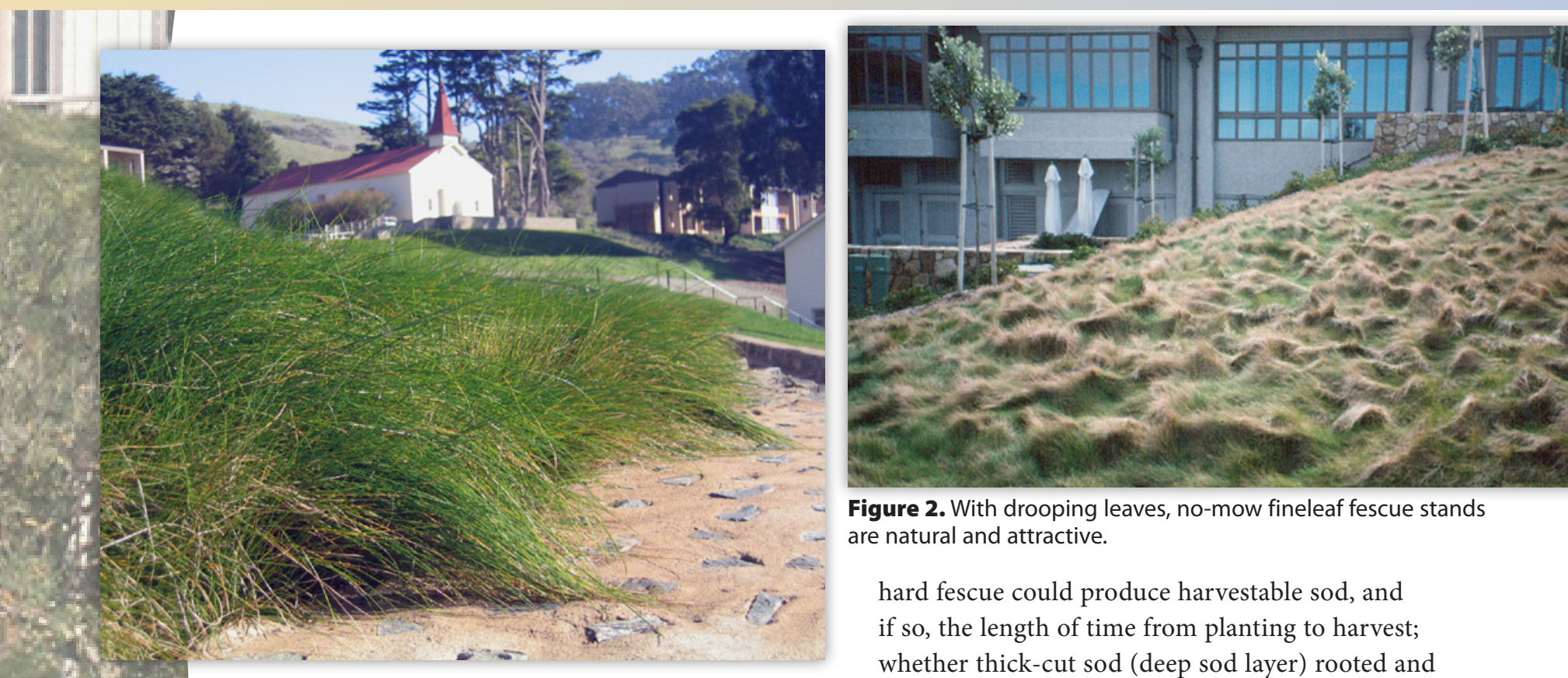

Figure 2. With drooping leaves, no-mow fineleaf fescue stands are natural and attractive.

hard fescue could produce harvestable sod, and if so, the length of time from planting to harvest; whether thick-cut sod (deep sod layer) rooted and established faster than thin-cut sod; and whether different rates of nitrogen fertilization before and after sod placement enhanced sod establishment, overall turf quality, and biomass production of a no-mow hard fescue stand.

This study demonstrated that hard fescue sod production was culturally feasible and yielded rapid stand establishment when transplanted. The main obstacle to sod production remains the relatively long growing period: hard fescue (and quite possibly other fineleaf fescue species) may require up to 9 months before being ready for harvest as sod. Other cool-season grasses, such as tall fescue (Festuca arundinacea), are ready for market as sod in less than half that time and are thus more economical for growers unless demand for fineleaf fescue is high enough to support higher prices.

Despite its long production time, hard fescue (and most other fineleaf fescues) sod can be established within 2 months in the landscape. Because fineleaf fescues remain an option for landscapers looking for a low-maintenance turf, the speed of sod establishment may justify the higher price. Direct seeding, by comparison, can take up to 2 years to produce a full cover. The 1996 study showed that hard fescue establishment is more rapid when sod is harvested at 1.5 inches thick than at 0.75 inch, and when at least 1 pound of nitrogen per 1,000 square feet is applied topically right after the sod is laid. Several mixtures of fineleaf fescues are currently available as sod and are marketed as no mow or optional mowing "lawns." 


\section{Selecting Fineleaf Fescue Species AND CUltivars}

Many new and improved fineleaf fescue species and cultivars have come to the California market in recent years. A UC trial from 2004 to 2007 evaluated the suitability and performance of these low-maintenance and drought-tolerant grasses in California's Central Coast climate (Harivandi and Morris 2009). In this trial, 53 fineleaf fescue cultivars were rated monthly for overall quality (turf score) under both mowed and no-mow regimes. The study included several cultivars each of strong creeping red fescue, slender creeping red fescue, Chewings fescue, hard fescue, and sheep fescue. Plots were established at a dedicated section of land at the Palo Alto Municipal Golf Course in full sun. All cultivars were planted on native soil at the rate of 4.4 pounds of seed per 1,000 square feet. Seed was broadcast by hand and raked in. A starter fertilizer was applied at seeding to provide 1 pound each of nitrogen, phosphorous, and potassium per 1,000 square feet. Cultivars were planted in a randomized complete-block design on 24-square-foot plots with 3 replications. Half of each plot was mowed at 2 inches weekly, and the other half was left unmowed for the entire trial period. Visual turf quality ratings were recorded separately for each plot, for both the mowed and no-mow turf.

To reflect the increased use of municipal recycled water for irrigation in urban settings, the plots were irrigated with a 50-50 blend of domestic and recycled water. Due to environmental restrictions at the golf course, no pesticide of any kind was applied to the plots; weed control was limited to occasional hand-pulling of weeds. Seasonal application of fertilizer provided approximately 2 pounds of nitrogen, 1 pound of of phosphorus, and 1 pound of potassium per 1,000 square feet per year. Plots were irrigated as needed.

Table 1 presents overall results at the end of the fourth year. Ratings are the averages of 4 years of monthly ratings (2004-2007). Ratings fall on a scale of 1 to 9 , with 9 representing superior cultivars for overall quality. Cultivars are ranked in table 1 from highest overall quality score to lowest.

The data revealed the following about the use of fineleaf fescues as monostand mowed
Table 1. Combined 4-year (2004-2007) mean overall turf quality (turf scores) for mowed and no-mow fineleaf fescue cultivars and species, in order of overall rank, in a trial at the Palo Alto Municipal Golf Course.

\begin{tabular}{|c|c|c|c|c|c|}
\hline \multirow{2}{*}{ Cultivar } & \multirow{2}{*}{ Species } & \multicolumn{2}{|c|}{ Mowed } & \multicolumn{2}{|c|}{ No-mow } \\
\hline & & Turf score & Rank & Turf score & Rank \\
\hline Fortitude & STC & 7.3 & 1 & 7.3 & 8 \\
\hline Cardinal & STC & 7.2 & 2 & 7.7 & 4 \\
\hline Epic & STC & 7.2 & 2 & 7.8 & 3 \\
\hline Wendy Jean & STC & 7.0 & 3 & 8.1 & 1 \\
\hline BMXC-S02 & STC & 6.9 & 4 & 7.9 & 2 \\
\hline C-SMX & STC & 6.9 & 4 & 7.8 & 3 \\
\hline Compass & $C$ & 6.9 & 4 & 7.5 & 6 \\
\hline Celestial & STC & 6.8 & 5 & 7.1 & 10 \\
\hline Dawson E & SLC & 6.8 & 5 & 7.7 & 4 \\
\hline DP 77-9885 & C & 6.8 & 5 & 6.6 & 15 \\
\hline DLF- RCM & STC & 6.7 & 6 & 7.8 & 3 \\
\hline Garnet & STC & 6.6 & 7 & 7.4 & 7 \\
\hline$J-5$ & C & 6.6 & 7 & 7.6 & 5 \\
\hline Musica & C & 6.6 & 7 & 7.2 & 9 \\
\hline C03-4676 & STC & 6.5 & 8 & 6.9 & 12 \\
\hline Class Ono & STC & 6.5 & 8 & 7.8 & 3 \\
\hline IS-FRR 23 & STC & 6.5 & 8 & 7.5 & 6 \\
\hline Jasper II & STC & 6.5 & 8 & 7.5 & 6 \\
\hline Lacrosse & C & 6.5 & 8 & 6.6 & 15 \\
\hline Razor & STC & 6.5 & 8 & 6.9 & 12 \\
\hline Shademaster & STC & 6.5 & 8 & 7.6 & 5 \\
\hline Cascade & C & 6.4 & 9 & 7.3 & 8 \\
\hline DP 77-9360 & STC & 6.4 & 9 & 7.3 & 8 \\
\hline DP 77-9578 & STC & 6.4 & 9 & 7.8 & 3 \\
\hline Longfellow II & C & 6.4 & 9 & 7.5 & 6 \\
\hline Oracle & STC & 6.4 & 9 & 7.0 & 11 \\
\hline Pathfinder & STC & 6.4 & 9 & 7.3 & 8 \\
\hline Shoreline & SLC & 6.4 & 9 & 7.4 & 7 \\
\hline Splendor & STC & 6.4 & 9 & 7.2 & 9 \\
\hline SR 5130 & $C$ & 6.4 & 9 & 6.7 & 14 \\
\hline TL1 & STC & 6.4 & 9 & 7.3 & 8 \\
\hline Zodiac & C & 6.4 & 9 & 7.0 & 11 \\
\hline Ambassador & C & 6.3 & 10 & 6.8 & 13 \\
\hline Culumbra II & C & 6.3 & 10 & 7.4 & 7 \\
\hline DP 77-9579 & STC & 6.3 & 10 & 7.4 & 7 \\
\hline Seabreeze & SLC & 6.3 & 10 & 7.3 & 8 \\
\hline 7 Seas & C & 6.2 & 11 & 6.9 & 12 \\
\hline Boreal & STC & 6.2 & 11 & 7.4 & 7 \\
\hline DP 77-9886 & C & 6.2 & 11 & 6.6 & 15 \\
\hline PST-8000 & STC & 6.2 & 11 & 6.7 & 14 \\
\hline Reliant IV & $\mathrm{H}$ & 6.2 & 11 & 7.3 & 8 \\
\hline Treazure II & C & 6.2 & 11 & 7.0 & 11 \\
\hline Spartan II & $\mathrm{H}$ & 6.1 & 12 & 6.1 & 18 \\
\hline Audobon & STC & 6.0 & 13 & 7.0 & 11 \\
\hline Berkshire & $\mathrm{H}$ & 6.0 & 13 & 6.7 & 14 \\
\hline Oxford & $\mathrm{H}$ & 6.0 & 13 & 7.2 & 9 \\
\hline Predator & $\mathrm{H}$ & 6.0 & 13 & 6.1 & 18 \\
\hline SR 3000 & $\mathrm{H}$ & 6.0 & 13 & 7.0 & 11 \\
\hline SRX 3K & $\mathrm{H}$ & 6.0 & 13 & 6.7 & 14 \\
\hline Firefly & $\mathrm{H}$ & 5.8 & 14 & 6.3 & 16 \\
\hline Scaldis & $\mathrm{H}$ & 5.8 & 14 & 6.1 & 18 \\
\hline Quatro & S & 5.6 & 15 & 6.2 & 17 \\
\hline Gotham & $\mathrm{H}$ & 5.5 & 16 & 6.2 & 17 \\
\hline $\operatorname{LSD}^{*}(0.05)$ & - & 0.8 & - & 0.7 & - \\
\hline
\end{tabular}

KEY:

C: Chewings fescue

$\mathrm{H}$ : hard fescue

S: sheep fescue

SLC: slender creeping red fescue

STC: strong creeping red fescue

Source: Harivandi and Morris 2009.

Note: *LSD: Least significant difference. To determine statistical differences among cultivars, subtract one cultivar's turf score from another's turf score. Statistical differences occur when this value is greater than the corresponding LSD value. If the difference between the turf score for two cultivars within the same column is not greater than the corresponding LSD, then the two cultivars are statistically the same, regardless of their ranking. 
or no-mow turf grown in full sun in central coastal California and irrigated with municipal recycled water.

- All cultivars remained green throughout the year. None experienced dormancy at any time during the year.

- Collectively, no-mow fineleaf fescue cultivars received higher turf scores (6.1-8.1) than the same cultivars mowed (5.5-7.3). A turf stand receiving a turf score below 6.0 is generally considered unacceptable.

- In past trials, hard fescue cultivars were top performers in turf quality among the fineleaf fescues. This trial countered that trend, as many strong creeping red fescue cultivars appeared at the top of the performance list under both mowed and no-mow regimens. Hard fescue cultivars (plus the

Table 2. Quality of irrigation water (recycled blend) used in the trial at the Palo Alto Municipal Golf Course.

\begin{tabular}{|c|c|c|}
\hline Parameter & Unit & Value* \\
\hline $\begin{array}{l}\text { electrical conductivity } \\
\text { (EC) }\end{array}$ & micromhos $/ \mathrm{cm}$ & 1,573 \\
\hline $\mathrm{pH}$ & - & 6.9 \\
\hline sodium & ppm & 197 \\
\hline calcium & ppm & 51 \\
\hline magnesium & ppm & 36 \\
\hline chloride & ppm & 307 \\
\hline boron & ppm & 0.33 \\
\hline chlorine (residual) & ppm & $4.9^{+}$ \\
\hline nitrate nitrogen $\left(\mathrm{NO}_{3}-\mathrm{N}\right)$ & ppm & 22 \\
\hline phosphate $\left(\mathrm{PO}_{4}\right)$ & ppm & 12 \\
\hline sulfate $\left(\mathrm{SO}_{4}\right)$ & ppm & 96 \\
\hline sodium adsorption ratio & - & 5 \\
\hline
\end{tabular}

lone sheep fescue) received the lowest turf scores under both mowing regimes.

- No disease activity was evident on any of the cultivars during the course of the study.

- Although fineleaf fescue cultivars were planted on clay soil and irrigated with moderately saline recycled water (electrical conductivity [EC] of $1.57 \mathrm{dS} / \mathrm{m}$ ), they generally performed well. With the exception of a few mowed hard fescue cultivars and the sheep fescue, they all produced an acceptable turf score (i.e., 6.0 or higher). Although the recycled irrigation water was moderately saline and sodic (sodium adsorption ratio [SAR] of 5), and had high levels of sodium (197 ppm) and chloride (307 ppm) (table 2), soil test results at the conclusion of the study (table 3 ) indicate only moderate soil salinity $\left(\mathrm{EC}_{\mathrm{e}}\right.$ of 1.43 ) and sodicity (SAR of 3 ). It appears that on this site natural precipitation in addition to the irrigation was sufficient to leach salts enough to prevent salt from accumulating to injurious levels. In a dry year, when natural precipitation and irrigation frequency may be limited and recycled water contains elevated salts, some of these cultivars may not perform as well as they did in this study.

\section{Fineleaf Fescue in the LANDSCAPE}

Based on field research, field observation, surveys, and input from industry personnel throughout California, it is clear that the turf and landscape industries now have the option of using fineleaf fescues as a low-maintenance, no-mow grassy ground cover. The results of a recent study (Harivandi and Morris 2009) indicate that fineleaf fescues can be grown successfully even when irrigation water (recycled water) is moderately saline. Infrequent or occasional mowing reduces maintenance costs and the same time addresses air and noise pollution concerns. Compared with popular tall fescue lawns, no-mow fine leaf fescues

Table 3. Plot soil chemical and physical characteristics at the beginning and conclusion of the trial at the Palo Alto Municipal Golf Course.

\begin{tabular}{|l|l|l|l|l|l|l|l|l|l|l|} 
& pH & $\begin{array}{l}\text { EC } \\
\text { dS/m }\end{array}$ & $\begin{array}{l}\text { Chloride } \\
\text { meq/l }\end{array}$ & $\begin{array}{l}\text { Bicarbonate } \\
\text { meq/I }\end{array}$ & SAR & ESP & CEC & $\begin{array}{l}\text { Sand } \\
\%\end{array}$ & Silt \% & Clay \% \\
\hline 2003 & 7.9 & 2.41 & 8.4 & 1.5 & 3 & 3 & 19.6 & 57 & 28 & 15 \\
\hline 2008 & 7.5 & 1.43 & 2.7 & 3.5 & 3 & 4 & 24.6 & 55 & 26 & 19 \\
\hline
\end{tabular}

$K E Y$ :

EC : electrical conductivity of saturated paste extract

SAR: sodium adsorption ratio

ESP: exchangeable sodium percentage

CEC: cation exchange capacity

Source: Harivandi and Morris 2009. 
are less prone to injury due to water deficiency stress during droughts, and they generally require less water, fertilizer, and pesticides. They are also more tolerant of shade and low $\mathrm{pH}$ than are all other California mowed lawn grasses. No-mow fineleaf fescues are aesthetically pleasing and can significantly reduce the cost of labor, fuel, water, fertilizers, and pesticides. Nevertheless, no-mow fineleaf fescue (or any other no-mow grass) is not suitable for sites where human traffic is common; they are not a replacement for typical backyard lawns, nor are they suitable for sport fields or playgrounds.

The following establishment and management recommendations are based on many years of field research and field observation. As new species and cultivars come to the market, more research and field experience will accumulate, and these recommendations may require modification.

\section{Establishment}

For both seeding and sodding of fineleaf fescue throughout California, best results are achieved if planting occurs from mid-September through October. Seeding fineleaf fescue from November through February is not recommended, as rain is likely to wash out the slow-germinating seed. The second-best time to seed fine fescue is in March and April, although higher temperatures in spring may increase the amount of water required for stand establishment. Seeding is not recommended from May to mid-September, as the slow-growing seedlings will be subjected to stress and possible injury from heat and drought during these warm months.

Spring is also the second-best choice for sodding. However, fineleaf fescue sod could also be laid during winter (recognizing that growth will be slow due to low temperature) or summer (accommodating the increased water need and increased likelihood of disease).

A seeding rate of 4.5 pounds per 1,000 square feet is recommended. Application of a starter fertilizer containing 1 pound each of nitrogen, phosphorous, and potassium lightly raked into the soil is required at seeding; topical application (followed by thorough irrigation) of the same kind and rate of fertilizer is appropriate immediately after the sod is laid.

Seeding fineleaf fescues on slopes can be challenging. Slow germination and seedling growth mean that the young seedlings are prone to "wash out" from rains or even irrigation. If possible, prepare a good seedbed by tilling-in an organic amendment and provide a balanced starter fertilizer to speed seedling growth. Depending on slope steepness, it is advisable to use hydroseeding, mulching, or erosion-control blankets. On slopes where neither good seedbed preparation nor the use of an erosion control blanket is practical, seeding a fast-growing "nurse" crop such as annual ryegrass (Lolium multiflorum) along with the fineleaf fescue seed is an option, although only in fall. (Annual ryegrass germinates quickly in fall or winter and grows fast enough to protect the soil from erosion from the rain.) One disadvantage of this method is that the annual ryegrass should either be mowed before seed head production or after fineleaf fescue establishment during the second or third season after planting. Furthermore, preemergent herbicides must be applied to prevent the perpetual presence of annual ryegrass. In addition, the fairly heavy biomass left on the stand after annual ryegrass dies in summer will slow establishment of the fineleaf fescue stand and should be removed, if practical.

Soil preparation for both seeding and sodding is similar to that for any type of lawn seeding and sodding: tilling, adding organic matter and fertilizer, leveling, raking, rolling, etc. Perennial weeds must be eliminated as much as possible; nonselective herbicides are the most effective tools in this effort.

After seeding and sodding, the site must be irrigated immediately. The top $1 / 4$ to $1 / 2$ inch of soil must be kept moist until the grass is well established.

\section{Irrigation}

Although no-mow fineleaf fescues require less water than typical mowed lawns, to survive in California they must be irrigated during summer months. Currently, no research-based information is available on the irrigation requirements of no-mow fineleaf fescues. Field observations, however, suggest that at any location, no-mow fineleaf fescue stands will do well and exhibit an acceptable green color when irrigated at about 85 percent of what is needed to keep a mowed tall fescue lawn green in the same area. That translates to a watering requirement of roughly 70 percent of the reference evapotranspiration $\left(\mathrm{ET}_{\mathrm{o}}\right)$. Although there is no research to substantiate these figures, field experience suggests that they are good starting 


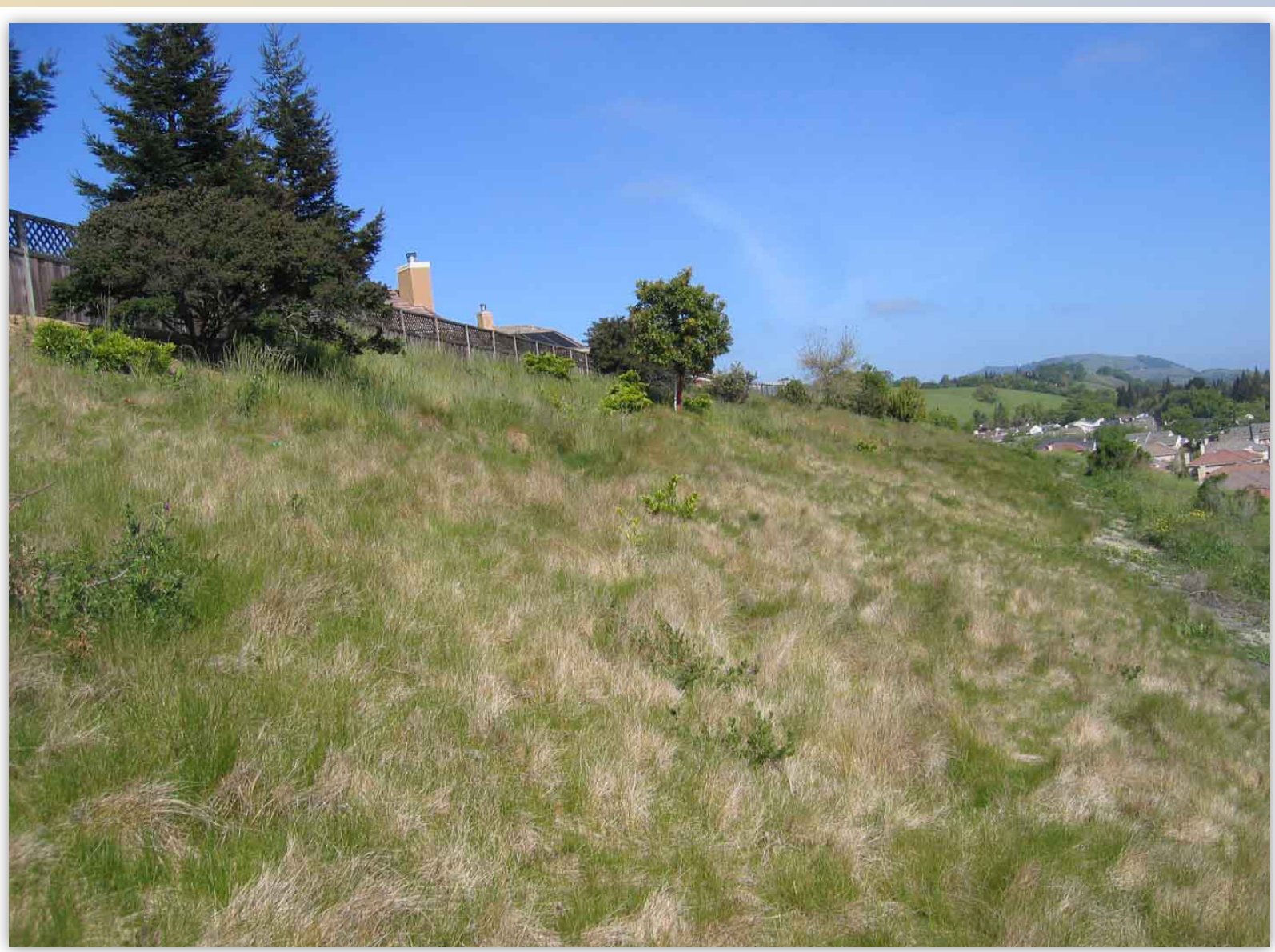

Figure 3. During summer months and under deficit irrigation, no-mow fineleaf fescue stands will go dormant.

points at any location. It is important to emphasize that the 70 percent $\mathrm{ET}_{\mathrm{o}}$ watering requirement specified here is not research based and is offered only as a rough estimate. In regions of California with very hot, dry summers, no-mow fineleaf fescues may require more water to keep the stand green and to prevent dormancy. On the other hand, stands established in shady or foggy areas may need less water than 70 percent $\mathrm{ET}_{\text {o. }}$.

Irrigation of no-mow fescues may be stopped after the first significant rain of the fall-winter season and should be restarted only after the chance of further rain disappears in spring. In mountainous regions of California, where soil freezes in winter, no-mow fineleaf fescue (like all other cool-season grasses) will be dormant and brown. Irrigation is not needed during this dormancy period.

If fineleaf fescue stands are irrigated at deficit irrigation (i.e., less than $70 \% \mathrm{ET}_{\mathrm{o}}$ ) during summer months, the grass stand may induce dormancy, the severity of which depends on the extent of the deficit (fig. 3). At very low or no irrigation, a stand may turn completely brown. Under severe, prolonged water deficit stress, fineleaf fescue may die. However, at least a couple of severe water deficit summer seasons may pass before the entire stand dies. Since fineleaf fescues produce relatively deep and extensive root systems, no-mow stands are able to tolerate longer periods of drought stress than are mowed stands.

Irrigating fineleaf fescue stands on slopes is a challenge. Overhead irrigation water often runs off the surface of foliage and thatch before reaching the soil and accumulates at the bottom of the slope, resulting in very wet areas at the bottom and dry areas at the top. As a result, the grass is prone to drought-induced injury (dormancy) at the top of the slope and diseases at the bottom. The most effective solution to this problem is installing lowvolume sprinkler heads at the top of the slope and running them longer while applying water at a low rate. Another option is to lay several parallel lines of drip tubes (such as Leakey Pipe) perpendicular to the slope on the surface of the soil at the time of planting. After the grass is established, these irrigation lines will disperse water at low rates on 

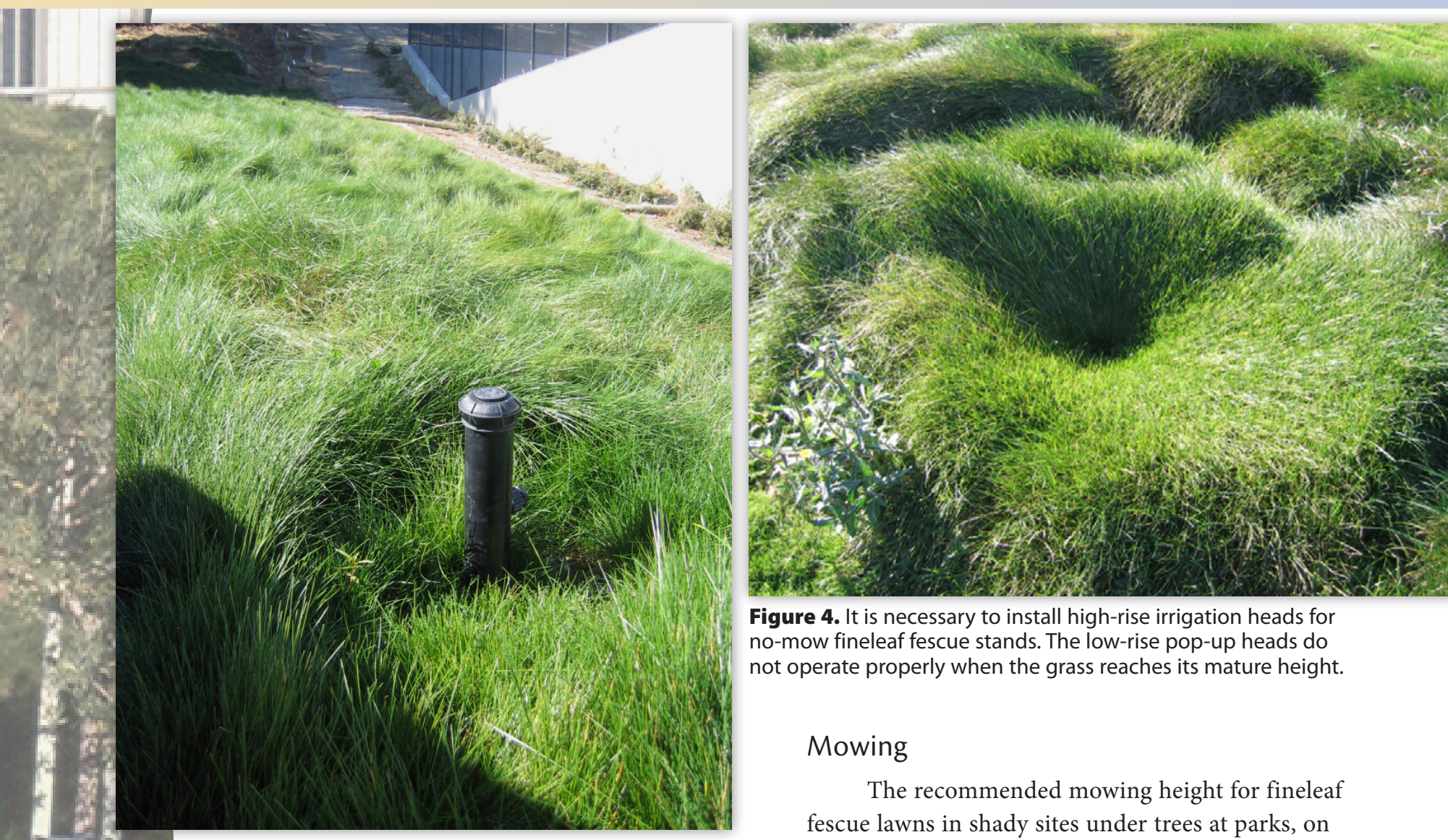

Figure 4. It is necessary to install high-rise irrigation heads for no-mow fineleaf fescue stands. The low-rise pop-up heads do not operate properly when the grass reaches its mature height.

\section{Mowing}

The recommended mowing height for fineleaf fescue lawns in shady sites under trees at parks, on golf courses, cemeteries, etc. is $2 \frac{1}{2}$ inches. Mowing once every 2 to 3 weeks may be sufficient. Most fineleaf fescue species and cultivars left unmowed will grow to a height 6 to 12 inches, with most leaves drooping to one side or the other. Some species and cultivars may produce seed heads, though these tend to be inconspicuous and low in number and generally add to the "natural" look of the stand. Seeds are generally not viable and will not reseed a thinned spot, nor will they significantly contaminate adjacent landscaping. If seed heads are objectionable, they can be removed annually using hand-held string trimmers. If, for either practical or aesthetic reasons, it is necessary to keep a shorter turf canopy than that of completely unmowed grass, the site may be mowed 1 to 4 times per year with the mower set at the highest setting. In this case, the abundant clippings must be removed to prevent them from interfering with regrowth of the stand. Also, the aesthetic value of the stand after such drastic mowing events may not be high for 2 to 4 weeks, (i.e., until new green growth masks the scalped grass). The best time for seasonal mowing is in the fall; the second best time is early spring. Where annual weeds are plentiful, it is advisable to diseases if wet for an extended period. 


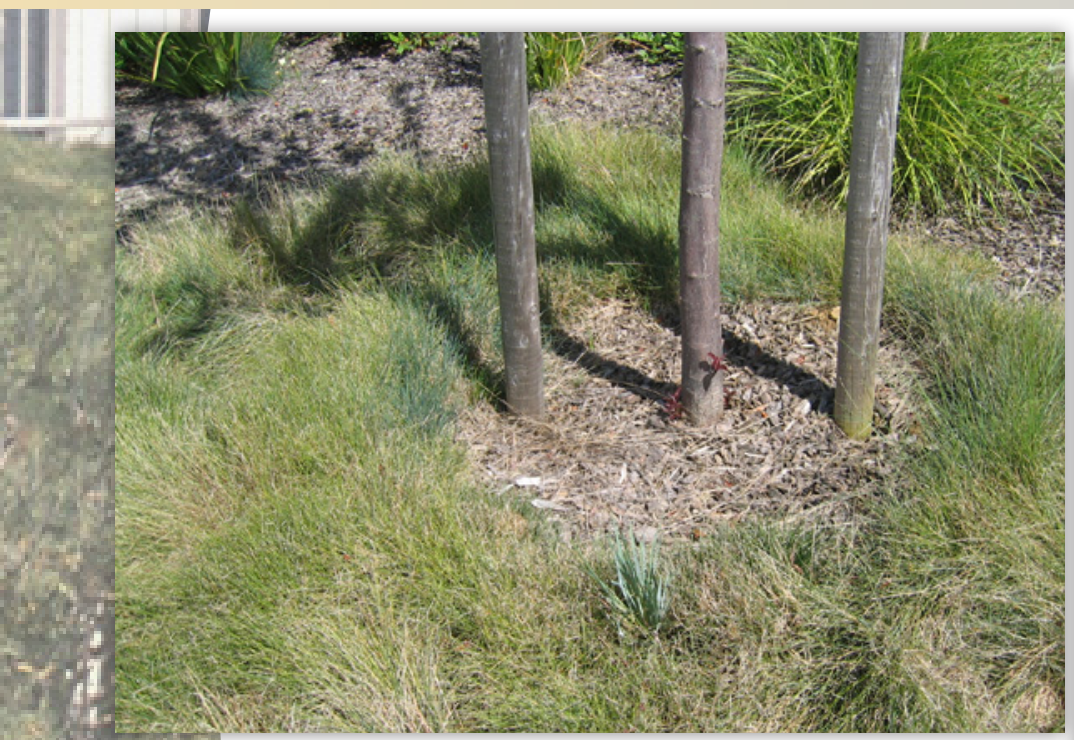

Figure 5. No-mow fineleaf fescue stands must be kept away from the tree trunks to prevent tree crown diseases.

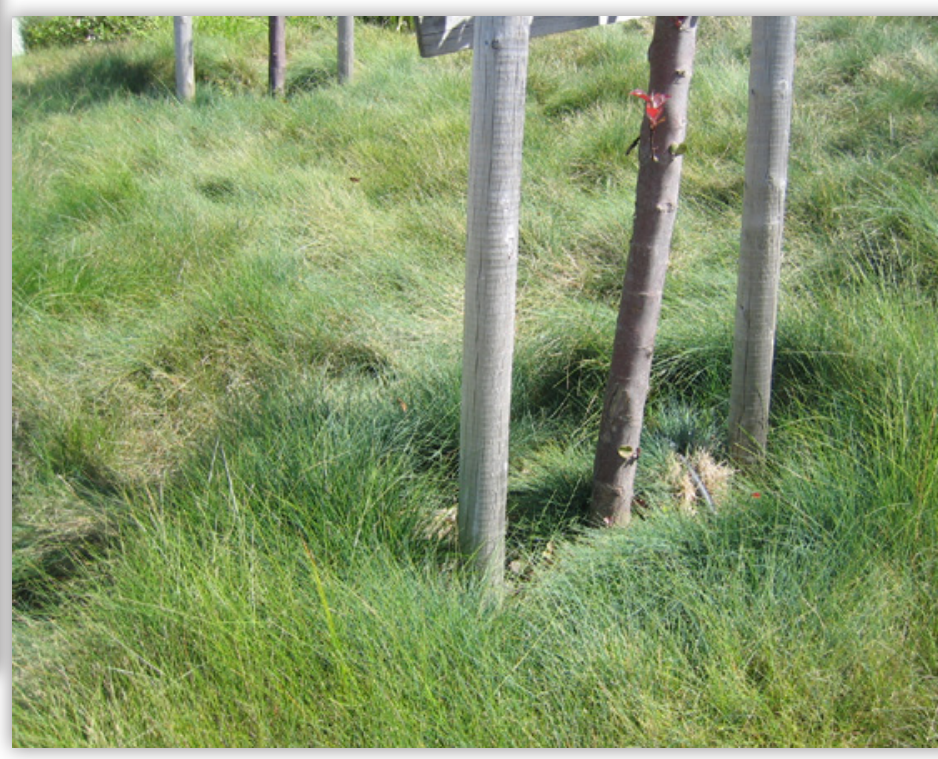

apply a preemergent herbicide after seasonal mowing to prevent weed establishment while the fescue plants are recuperating.

No-mow fineleaf fescue growing near or around landscape trees and shrubs may create a problem. Tall, dense grass abutting trees or shrubs may provide a thick layer of continuously moist (or at least damp) mulch that can promote fungus and crown rot. To prevent disease, keep grass at least 2 feet from tree trunks or shrubs. Similarly, remove already-established grass that is closer than 2 feet to trunks (fig. 5).

\section{Fertilization}

One of the advantages of a no-mow fineleaf fescue stand is that it needs less nutrition than a mowed stand. If the soil is highly fertile, a no-mow stand of fineleaf fescue may never need to be fertilized. On average soils, the stand may need no more than no-mow fineleaf fescues are grown on fertile California soils, application of them in commonly marketed turf fertilizers should not cause a problem.

While application of additional nitrogen may make no-mow fineleaf fescue greener, excessive nitrogen also encourages excessive and unnecessary growth and thatch. Excessive thatch is undesirable, as the stand will become progressively puffy and clumpy, more prone to disease, and harder to irrigate effectively.

\section{Weed Control}

Extremely slow seed germination and seedling growth create challenges for weed control at early stages of turf establishment (fig. 6). In California, many weeds are

Figure 6. Weed invasion could be a challenge when establishing no-mow fineleaf fescues from seed. 1 pound of nitrogen per 1,000 square feet per year. If the stand is planted on infertile soils (e.g., subsoils, roadside slopes) or sandy soils, more fertilizer may be needed. Fertilizers that combine slow-release and fast-acting (soluble) forms of nitrogen are preferable. The best time to fertilize is October, before the rain arrives. Only on sandy soils should other nutrients such as phosphorous and potassium be applied, and then at a rate of 1 pound per 1,000 square feet per year of each. Although neither of these nutrients is necessary if

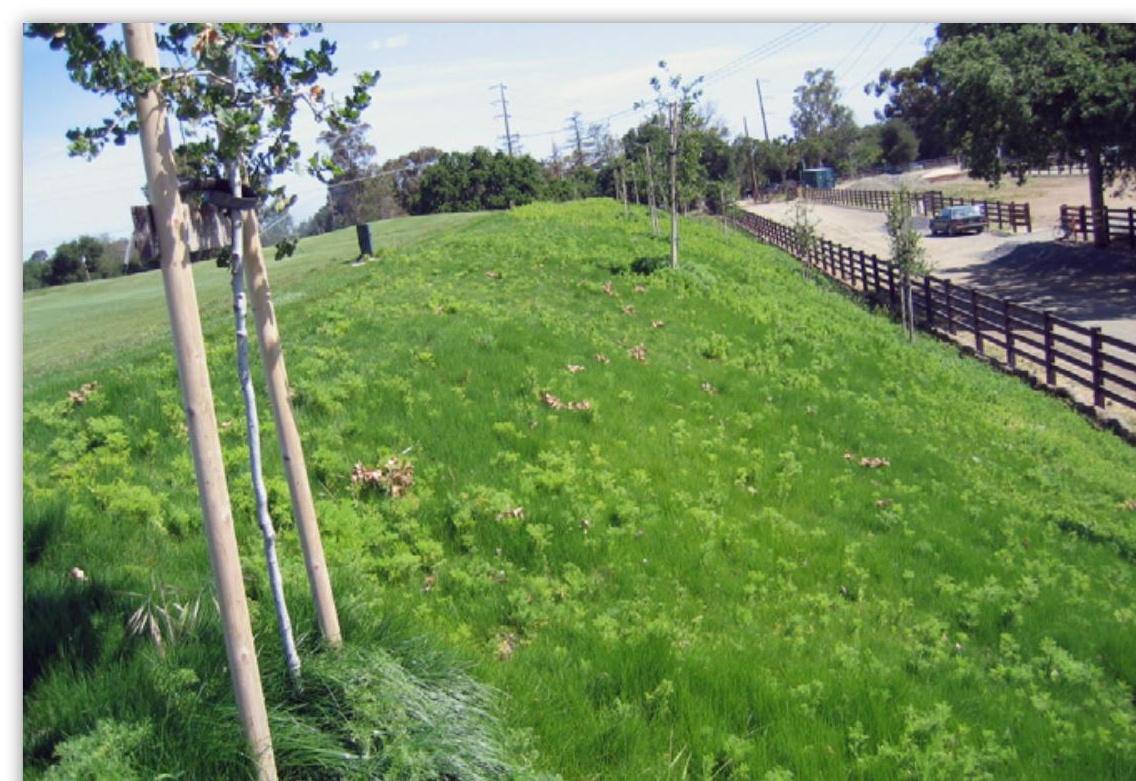


well adapted and have naturalized. With practically no competition from slow-growing fineleaf fescue seedlings, local weeds can easily take over the stand for the first year or two. Application of either pre- or postemergent herbicides is not recommended during the first, and possibly second, season after seeding, as fineleaf fescue seed germination and seedling growth may also be curtailed, and new seedlings are susceptible to herbicide injury. The most effective way to slow the spread of weeds during the first or second season of growth is mowing. Setting the mower at (4 to 8 inches) just above the average height of the fineleaf fescue stand will stop weeds from producing seed heads, lower the weed population, and, in time, reduce the shading and competition from weeds. As a fineleaf fescue stand becomes established (within a year or two), most annual weeds will be eliminated because their seeds will have difficulty getting established. Eventually, as the fineleaf fescue grows taller and becomes more dense, many perennial weeds will be crowded out. Any remaining weeds can be controlled from the third season after seeding with pre- or postemergent herbicides. On established no-mow fineleaf fescue stands, spot application of a broadleaf herbicide is effective and is preferable to blanket application. To get the best results (and for plant, animal, and human safety), follow the directions given on any pesticide label.

The biggest advantage of sodding fineleaf fescue over seeding is the elimination of weeds. Fortunately, producers are increasingly offering fineleaf fescue sod. Although initially more expensive, sod may be a better economic choice, considering weed infestation, seedling disease, seed wash out, etc., that can affect seedling establishment.

\section{Disease Management}

Fineleaf fescues are susceptible to common local turfgrass diseases when mowed. When unmowed, the incidence of disease development is relatively low. Even where disease infects a no-mow stand, the infestation is often localized since the disease is not spread through the sward by mowers or human traffic. If a localized diseased area is large and cannot be ignored, spot application of an appropriate turfgrass fungicide may be required. It may also be prudent to "wait and see" before chemical treatment. If a disease kills the grass (i.e., the spot does not recover), remove dead tissue, till the soil in that spot shallowly, and reseed or resod with fineleaf fescue.

\section{Insect Pests}

No significant insect damage of no-mow fineleaf fescue stands has been reported in California, although with the increase in planted acreage of these grasses, insect damage could become an issue in the future.

\section{Rodents}

Rodents (gophers, moles, squirrels, rats, etc.) do not appear to be a problem in no-mow fineleaf fescue stands. It may be that the dense thatch layer that eventually develops in no-mow stands discourages rodent activity. Or, although minor infestation may occur, the symptoms (e.g. soil mounds) may not be visible.

\section{References}

Harivandi, M. A., and K. N. Morris. 2009. The use of non-mowed fine-leaf fescue grasses on golf courses. USGA Green Section Record 47(6): 20-28.

Harivandi, M. A., W. L. Hagan, M. Z. Mousli, and L. Wu. 2004. Establishing hard fescue from sod. HortTechnology 14(1): 88-90.

\section{English-Metric Conversions}

\begin{tabular}{|l|c|c|c|}
\hline English & $\begin{array}{c}\text { Conversion factor for } \\
\text { English to Metric }\end{array}$ & $\begin{array}{c}\text { Conversion factor for } \\
\text { Metric to English }\end{array}$ & Metric \\
\hline inch (in) & 2.54 & 0.394 & square meter $\left(\mathrm{m}^{2}\right)$ \\
\hline square foot $\left(\mathrm{ft}{ }^{2}\right)$ & 0.0929 & 10.764 & kilogram $(\mathrm{kg})$ \\
\hline pound $(\mathrm{lb})$ & 0.454 & 2.205 & kilogram per hectare $(\mathrm{kg} / \mathrm{ha})$ \\
\hline pound per acre $(\mathrm{lb} / \mathrm{ac})$ & 1.12 & 0.89 & $\mathrm{~cm})$ \\
\hline
\end{tabular}




\section{FOR FURTHER INFORMATION}

To order or obtain ANR publications and other products, visit the ANR Communication Services online catalog at http://anrcatalog.ucdavis.edu or phone 1-800-994-8849. You can also place orders by mail or FAX, or request a printed catalog of our products from

University of California

Agriculture and Natural Resources

Communication Services

6701 San Pablo Avenue, 2nd Floor

Oakland, California 94608-1239

Telephone 1-800-994-8849

510-642-2431

FAX 510-643-5470

E-mail: danrcs@ucdavis.edu

(C2010 The Regents of the University of California

Agriculture and Natural Resources

All rights reserved.

No part of this publication may be reproduced, stored in a retrieval system, or transmitted, in any form or by any means, electronic, mechanical, photocopying, recording, or otherwise, without the written permission of the publisher and the authors.

Publication 8391

\section{ISBN-13: 978-1-60107-666-3}

Photographs by Ali Harivandi.

The University of California prohibits discrimination or harassment of any person on the basis of race, color, national origin, religion, sex, gender identity, pregnancy (including childbirth, and medical conditions related to pregnancy or childbirth), physical or mental disability, medical condition (cancer-related or genetic characteristics), ancestry, marital status, age, sexual orientation, citizenship, or service in the uniformed services (as defined by the Uniformed Services Employment and Reemployment Rights Act of 1994: service in the uniformed services includes membership, application for membership, performance of service, application for service, or obligation for service in the uniformed services) in any of its programs or activities.
University policy also prohibits reprisal or retaliation against any person in any of its programs or activities for making a complaint of discrimination or sexual harassment or for using or participating in the investigation or resolution process of any such complaint.

University policy is intended to be consistent with the provisions of applicable State and Federal laws.

Inquiries regarding the University's nondiscrimination policies may be directed to the Affirmative Action/Equal Opportunity Director, University of California, Agriculture and Natural Resources, 1111 Franklin Street, $6^{\text {th }}$ Floor, Oakland, CA 94607, (510) 987-0096. For information about ordering this publication, telephone 1-800-994-8849. For assistance in downloading this publication, telephone 530-754-3927.

To simplify information, trade names of products have been used. No endorsement of named or illustrated products is intended, nor is criticism implied of similar products that are not mentioned or illustrated.

An electronic copy of this publication can be found at the ANR Communication Services catalog Web site, http://anrcatalog.ucdavis.edu.

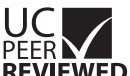

This publication has been anonymously peer reviewed for technical accuracy by University of California scientists and other qualified professionals. This review process was managed by the ANR Associate Editor for Environmental Horticulture.

web-03/10-SB/CR 